IZA DP No. 8417

How Selective Are Real Wage Cuts?

A Micro-Analysis Using Linked Employer-Employee Data

Boris Hirsch

Thomas Zwick

August 2014

Forschungsinstitut zur Zukunft der Arbeit Institute for the Study of Labor 


\title{
How Selective Are Real Wage Cuts? A Micro-Analysis Using Linked Employer-Employee Data
}

\author{
Boris Hirsch \\ University of Erlangen-Nuremberg \\ and IZA \\ Thomas Zwick \\ University of Würzburg, \\ ZEW and ROA \\ Discussion Paper No. 8417
August 2014 \\ IZA \\ P.O. Box 7240 \\ 53072 Bonn \\ Germany \\ Phone: +49-228-3894-0 \\ Fax: +49-228-3894-180 \\ E-mail: iza@iza.org
}

Any opinions expressed here are those of the author(s) and not those of IZA. Research published in this series may include views on policy, but the institute itself takes no institutional policy positions. The IZA research network is committed to the IZA Guiding Principles of Research Integrity.

The Institute for the Study of Labor (IZA) in Bonn is a local and virtual international research center and a place of communication between science, politics and business. IZA is an independent nonprofit organization supported by Deutsche Post Foundation. The center is associated with the University of Bonn and offers a stimulating research environment through its international network, workshops and conferences, data service, project support, research visits and doctoral program. IZA engages in (i) original and internationally competitive research in all fields of labor economics, (ii) development of policy concepts, and (iii) dissemination of research results and concepts to the interested public.

IZA Discussion Papers often represent preliminary work and are circulated to encourage discussion. Citation of such a paper should account for its provisional character. A revised version may be available directly from the author. 


\begin{abstract}

\section{How Selective Are Real Wage Cuts? A Micro-Analysis Using Linked Employer-Employee Data*}

Using linked employer-employee panel data for Germany, this paper investigates whether firms implement real wage reductions in a selective manner. In line with insider-outsider and several strands of efficiency wage theory, we find strong evidence for selective wage cuts with high-productivity workers being spared even when controlling for permanent differences in firms' wage policies. In contrast to some recent contributions stressing fairness considerations, we also find that wage cuts increase wage dispersion among peers rather than narrowing it. Notably, the same selectivity pattern shows up when restricting our analysis to firms covered by collective agreements or having a works council.
\end{abstract}

JEL Classification: $\quad \mathrm{J} 30, \mathrm{~J} 31$

Keywords: real wage rigidity, real wage cuts, selectivity, Germany

Corresponding author:

Boris Hirsch

University of Erlangen-Nuremberg

Chair of Labour and Regional Economics

Lange Gasse 20

90403 Nuremberg

Germany

E-mail: boris.hirsch@fau.de

\footnotetext{
*We are grateful to Florian Englmaier, Clemens Fuest, Steffen Müller, Claus Schnabel, and Carmit Segal for useful comments and suggestions. We further appreciate the comments received from participants of the 2013 Colloquium on Personnel Economics in Tübingen and the 2013 BGPE research workshop in Bamberg.
} 


\section{Introduction}

There is overwhelming evidence that workers face a low risk of being hit by wage reductions (e.g. Kahn, 1997; Dickens et al., 2007; Babecký et al., 2010). For instance, Dustmann and Schönberg (2009) report that in Germany during the period 1996-1999 less than ten per cent of young workers working full-time hours experienced an annual decrease in real wages of five per cent or more. Theoretically, firms' reluctance to reduce real wages is typically explained in terms of implicit contract theory with employers insuring workers against real income losses (e.g. Baily, 1974; Azariadis, 1975), efficiency wage theory with firms shying away from the adverse consequences of wage cuts on worker effort, turnover, and quality (e.g. Yellen, 1984), and insider-outsider theory with insiders possessing considerable bargaining power to obviate wage reductions (e.g. Lindbeck and Snower, 1988). ${ }^{1}$

Whereas numerous empirical studies document that these theories are likely to contribute to the low incidence of real wage cuts (e.g. Campbell and Kamlani, 1997; Bewley, 1999; Franz and Pfeiffer, 2006; Agell and Bennmarker, 2007; Babecký et al., 2010; Du Caju et al., 2012b), existing studies - with the notable exceptions of Böckerman et al. (2007) and Du Caju et al. (2012a,b) - do not investigate differences in workers' individual risk of being exposed to real wage reductions. Therefore, there is only scant direct evidence on which groups of workers are disproportionally hit by wage reductions taking all other firm and workforce characteristics into account. Yet, we should expect to find such differences given our theoretical priors based for example on the shirking model (Shapiro and Stiglitz, 1984). That said, efficiency wage models based on fairness considerations (Akerlof, 1982; Akerlof and Yellen,

1 In our analysis, we will mainly follow Dustmann and Schönberg (2009) and define a real wage cut as a reduction in the real wage of five per cent or more relative to the previous year thereby ensuring that the wage cut is substantial enough to be felt by workers. As in our period of observation, inflation was well below five per cent, a real wage reduction coincides with a nominal wage reduction, and our analysis is also informative on the selectivity of nominal wage reductions. Yet our theoretical arguments for selective wage reductions are concerned with real rather than nominal, so we will restrict attention to real wage reductions in the following and only report the results for a nominal wage cut as a robustness check. 
1990) suggest selective wage reductions may be deemed unfair by workers, so that firms may be reluctant to implement selective wage cuts.

It is thus an open question ex ante whether firms actually resort to selective wage cuts the point at the heart of this paper's contribution to the literature. Most of the evidence on selective wage cuts comes from employer surveys and lab experiments, we are however able to use linked employer-employee data for Germany that allow us to analyse workers’ individual risk of experiencing a real wage cut and whether some employee groups are disproportionally hit by wage reductions given an employer has to cut wages. In a first step, we investigate which individual and employer characteristics affect the probability that a worker faces a real wage reduction. In a next step, we include firm fixed effects to our model to control for permanent differences in firms' wage policies. Finally, we add workers' wage residual estimated from an extended Mincerian wage regression for the previous year including a broad range of individual characteristics as well as firm fixed effects. Including the wage residual allows us to test whether employers spare high-performance workers from real wage cuts to prevent them from lowering their effort or leaving the firm, or rather cut wages in such a way reducing the wage dispersion among peers to promote fairness.

The remainder of this paper is organised as follows: In Section 2, we summarise the theoretical and empirical literature on real wage reductions and derive our hypotheses which determinants are likely to affect workers' individual probability of facing a real wage reduction. Section 3 describes our data and Section 4 our econometric approach. Section 5 presents and discusses our results, and Section 6 concludes. 


\section{Existing Literature and Hypotheses}

\subsection{Efficiency Wage Theory}

As stressed in the introduction, real wage cuts are rarely observed in real-world labour markets with efficiency wage, insider-outsider, and implicit contract theory providing explanations for this finding. According to efficiency wage theory, firms gain from paying wages above the market-clearing level, and wage reductions would thus put these gains at stake. Paying higherthan-necessary wages is expected to (i) reduce worker shirking (Shapiro and Stiglitz, 1984), (ii) depress turnover thereby lowering hiring and training costs (Stiglitz, 1974), (iii) improve the average quality of job applicants (Weiss, 1980), and (iv) increase workers' effort due to social norms and fairness standards (Akerlof, 1982; Akerlof and Yellen, 1990). Existing evidence from employer surveys suggests that efficiency wage considerations indeed play an important role in explaining the low incidence of wage reductions (Campbell and Kamlani, 1997; Franz and Pfeiffer, 2006; Agell and Bennmarker, 2007; Babecký et al., 2010). Moreover, efficiency wage theories give rise to clear predictions on selective wage reductions. Shirking, labour turnover, and adverse selection models obviously provide rationales for selective wage reductions, as we shall detail below, whereas fairness considerations may leave firms to resort to selective wage reductions to a much lesser extent.

In Shapiro and Stiglitz's (1984) shirking model, paying wages above the marketclearing level results in equilibrium unemployment that prevents workers from shirking because the queues of job applicants render a job loss costly to them. As a consequence, the increase in labour cost is compensated for by a rise in worker productivity, and firms are expected to be reluctant to cut wages lest to spoil this positive productivity effect. These considerations also make clear why we should expect to find selective wage reductions. In general, firms should spare high-productivity workers such as high-skilled workers from wage cuts as shirking of 
these individuals is likely to greatly influence firms’ profits. In a similar vein, firms should also spare workers with a high wage residual (given important observable characteristics that explain differences in productivity), which we will consider as a measure of individuals' unobserved performance in the firm (details are given in Sections 4 and 5 where we discuss our econometric approach and results). We also expect firms to be more reluctant to cut wages for workers whose output is more difficult to monitor like high-skilled or high-productivity workers, who are more likely to perform non-standard tasks (Babecký et al., 2010; Du Caju et al., 2012b). Furthermore, monitoring is likely to be more costly in large firms (Oi and Idson, 1999) that may therefore refrain to a greater extent from wage cuts. What is more, for firms operating in East Germany, which still shows a much poorer labour market performance than West Germany, wage cuts are likely to be less harmful.

Other than the shirking model, in Stiglitz' (1974) labour turnover model, efficiency wages are paid to decrease worker turnover resulting in savings on hiring and training costs. These savings compensate for the increase in labour cost. ${ }^{2}$ Furthermore, efficiency wages raise the average unobserved quality of the pool of firms’ job applicants in Weiss' (1980) adverse selection model. Since turnover is particularly costly in case of high-productivity workers and these workers also have the highest propensity to quit in response to wage reductions in the adverse selection model, the labour turnover and the adverse selection model point at the same individual determinants of individual wage cuts as the shirking model (Du Caju et al., 2012b).

Another remarkable point was made by Howitt (2002): wage reductions should be less prevalent if labour costs are just a small part of total costs because in this case negative effects on productivity are likely to dominate positive labour cost effects on profits. Extending this argument to different subgroups of workers, we expect that an individual's probability of being hit by a real wage cut is larger if the share of workers with the same individual characteristics

2 In line with this, Cornelißen and Hübler (2008) find for Germany that downward wage rigidity has a significantly negative impact on worker turnover. 
in the firm's workforce is higher, as a larger share of similar workers in the workforce causes selective wage cuts for this group of workers to have a bigger impact on the firm's labour costs. Alluding to the well-known fourth Hicks-Marshall rule of derived labour demand, we will refer to the hypothesis that selective wage cuts are more likely for groups of workers representing a large part of the firm's workforce as the "importance of being unimportant”.

\subsection{Insider-Outsider Theory}

On top of efficiency wage theory, insider-outsider theory stresses that insiders possess bargaining power in the wage-setting process (Lindbeck and Snower, 1988), which they may well be able to use to prevent firms from implementing wage reductions. Obviously, different groups of workers may differ in their bargaining power. As a case in point, workers possessing high levels of specific human capital, i.e. more tenured workers, may be exempted from wage reductions (Holden, 1994; Malcomson, 1997). Implicit seniority wage contracts may be in place with high-tenured workers earning more than their actual productivity, however. As these workers may thus lack outside options offering comparable earnings, firms may be less reluctant to cut wages for high-tenure workers (Lazear, 1979). This argument is also in line with the finding by Blinder and Choi (1990) that firms tend to cut wages for workers earning above-productivity wages.

Insiders' bargaining power is also likely to be influenced by several firm characteristics such as the industrial relations regime or the profit situation. In Germany, industrial relations are characterised by a dual system of worker representation through trade unions and works councils (for details, see Addison et al., 2010). In firms covered by collective agreements or having a works council, insiders should possess more bargaining power enabling them to prevent wage cuts to a greater extent. Moreover, these institutions may also foster implicit contracts, which are another reason given for the low incidence of real wage reductions. In 
particular, collective agreements at sector level are likely to prevent wage reductions, whereas this may hold to a lesser extent for collective agreements at firm level (Gürtzgen, 2009). Gartner et al. (2013) stress, however, that the existence of works councils or unions may also cause workers to regard real wage cuts as fair. For example, works councils may be able to credibly convince workers that wage moderation is necessary to increase competitiveness. Furthermore, in firms bound by collective agreements, wage cuts may not be perceived as unilaterally imposed by management. Finally, firms with a good profit situation can be expected to shy away from wage cuts and to share rents with their employees instead (Arai, 2003; Gützgen, 2009).

\subsection{Fairness Considerations}

Other than the efficiency wage and insider-outsider theories discussed so far, fairness considerations and the related empirical literature arrive at conclusions less favourable for selective real wage cuts. According to fairness models, firms abstain from reducing wages because workers are likely to lower effort due to reciprocity. As wage cuts are usually perceived as damaging by management, the empirical evidence on the reciprocity effects of wage reductions mainly relies on interview and survey studies. Two rare exemptions are the field experiments in Cohn et al. (2011) and Kube et al. (2013). In a natural field experiment, Kube et al. (2013) find that workers who had been hired at a certain wage showed significantly lower performance when starting the job and receiving a lower wage than expected. ${ }^{3}$ Furthermore, in a randomised field experiment, Cohn et al. (2011) observe teams of two salesmen in a temporary promotion campaign. Whereas a general wage cut to both team members is found to

3 There are also some case studies on the effect of wage reductions on effort. For instance, Lee and Rupp (2007) find only a small and short-lived negative impact on effort following large and permanent pay cuts for commercial airline pilots in the US. They argue that this surprising result may be driven by this employee group's poor outside options during their period of observation and high absolute remuneration levels even after the pay cuts. 
significantly decrease the team's overall performance, a selective wage reduction has even worse consequences: reducing the wage for just one team member triggers a drop in this team member's performance that is more than twice the size of the overall drop in performance from a general wage reduction. Consequently, firms should generally avoid selective wage cuts.

That said, fairness considerations also stress that newly hired workers who lack a long history of interactions with the management and an established position in the firm are likely to possess looser fairness standards than more senior workers; they should thus accept a wage cut more easily (Fehr and Götte, 2005). Finally, from interviews with managers Blinder and Choi (1990) document that firms tend to reduce wages for workers who earn more than comparable workers for fairness standards. We should therefore expect firms to implement selective wage cuts among observationally similar workers, such as for those with positive wage residuals, in order to reduce wage dispersion among peers.

\subsection{Summary of Hypotheses and Econometric Specification}

All in all, we therefore arrive at the following characteristics likely to influence individuals' probability of being hit by a real wage reduction, provided that firms implement selective wage cuts: individual characteristics likely to matter are skills, tenure, and the wage residual. Whereas high-skilled individuals are expected to face a lower risk of a real wage cut, the effects of the wage residual and tenure could be either positive or negative. In particular, the effect of the wage residual allows us to test whether individuals with high unobserved performance are exempted from wage reductions or whether they face a higher risk of wage cuts, as these are used to reduce the wage dispersion among peers due to fairness considerations. To investigate which groups of workers are disproportionally hit by wage reductions, the share of workers with a real wage reduction and interactions of this share with individual characteristics are added. Next, interactions of individual characteristics and the share of individuals with the very 
same characteristics in the workforce are included to see whether the selectivity of wage cuts is larger for groups of workers forming a large part of the firm's workforce, i.e. whether it is indeed important to be unimportant. Finally, plant characteristics likely to matter are those capturing the industrial relations regime, the profit situation, and firm size.

\subsection{Existing Evidence and Contribution to the Literature}

The literature on wage rigidity ${ }^{4}$ is frequently focused on statistical differences between wage increases and wage decreases and the extent of nominal and real wage rigidities that can be derived from them. Many papers for example identify wage rigidities by a comparison of the observed distribution of wage changes with a distribution that would prevail under perfect wage flexibility, for a short literature survey for example see Du Caju et al. (2012b). The International Wage Flexibility Project collected data on individual wage changes of job stayers from thirteen countries (Dickens et al., 2007). It analyses the extent of real and nominal wage rigidity by comparing the extent of wage increases and decreases (Kahn, 1997; Dickens and Götte, 2006).

Dickens et al. (2007) argue that countries with a stronger union presence are characterised by stronger wage rigidity. Comparable econometric approaches can be found for example in Knoppik and Beissinger (2003) for Germany and Du Caju et al. (2012a,b) for Belgium. These papers focus on the existence and extent of real and nominal wage rigidity and just control for individual characteristics in order to avoid biases from composition changes or split the sample into different sub-groups of workers, firms or sector in order to detect differences between these groups.

Another line of the literature uses individual wage changes of stayers in order to analyse the impact of shocks on the establishment level (Guiso et al., 2005; Cardoso and Portela, 2009;

\footnotetext{
4 We only include literature based on individual wages in our literature review. Therefore papers for example on aggregate wage changes within occupations (Campbell, 1997) or establishments (Kim et al., 2014) are not covered.
} 
Gürtzgen, 2014) or macro-economic shocks such as unemployment changes (Devereux, 2001; Devereux and Hart, 2006; Anger, 2011) on wages changes. These papers especially look at the correlation between the size of shocks, firm size as well as wage-setting institutions and negative wage changes ${ }^{5}$. Also in this line of the literature the existence and extent of real and nominal wage changes is central and individual characteristics of employees are mainly included to avoid biases or observe bivariate differences between groups of workers, firms or sectors.

To the best of our knowledge, the only studies that investigate the impact of individual and firm characteristics on the basis of individual workers' probability of experiencing a real wage cut are Böckerman et al. (2007) with longitudinal payroll data for all workers in Finland and Du Caju et al. (2012a,b) with matched employer-employee panel data for Belgium. The latter papers calculate differences in the incidence of real wage cuts by using reduced samples for three age groups, two occupation groups and 15 sectors and formally test differences between these samples. ${ }^{6}$ In a second approach, they explain sector difference in the incidence real wage rigidity by differences in average age, share of blue collar workers, bargaining regime, firm sizes, and capital-labour ratios.

In the following, we try to improve on the existing evidence in several ways: Analogously to Böckerman et al. (2007), we investigate the joint impact of worker and firm characteristics on workers' probability of experiencing a real wage reduction. Our large data set for Germany allows us to base our investigation on a homogenous sample of young workers starting their first job - we only include employees with a maximum of five (or in a robustness

5 We should add that another line of the literature is based on survey evidence of managers or human resource managers (Bewley, 1997; Franz and Pfeiffer, 2006; Agell and Bennmarker, 2007; Babecký et al., 2010; Du Caju et al., 2013).

6 Note that this approach implies that differences between groups are fully attributed to one dimension. Joint differences between for example tenure and gender or firm size and collective bargaining coverage cannot be jointly controlled for. 
check ten) years of tenure in their first job. ${ }^{7}$ This sample reduction allows us to eliminate unobserved heterogeneity between workers with respect to labour market histories and entry conditions that may be related to the risk of being hit by real wage reduction. Von Wachter and Bender (2006) for example show that wages of employer movers after apprenticeship training catch up with wages of stayers during the following years - this might mean that employer movers are systematically stronger shielded against wage cuts than those who have a longer tenure.

Entry wages and therefore probably rents of job entrants differ during the business cycle (Flinn, 1986; Von Wachter and Bender, 2006; Kahn, 2013; Stüber, 2013). When firms more than proportionally cut wages of employees with rents in comparison to their peers, cohorts who profited from favourable labour market conditions when they entered the labour market might be stronger affected by wage cuts. We therefore control for year of entry and therefore include business cycle effects on rents and wage changes. In addition, workers with different tenure are likely to show differences in their characteristics that are unobservable in our data, such as the attendance to (certified) training courses or certificates from previous employers. Training incidence is however correlated to wage changes (Zwick, 2011).

Since we use linked employer-employee data comprising almost all workers of a sample of firms who are covered by the social security system, we are also able to control for permanent firm differences in pay policies by including firm fixed effects. Furthermore, we are able to investigate which groups of firms' workers are disproportionally hit by wage cuts. As our data include detailed information on firms' workforce composition, we can also test the “importance of being unimportant” hypothesis, i.e. whether groups of workers with certain characteristics who represent a small block of firms’ employment and labour costs are less frequent subject to

\footnotetext{
As apprentices usually experience automatic yearly wage increases during their apprenticeship period, we exclude workers during their apprenticeship and consider those in their first skilled employment instead. Therefore, the equality of workers' experience and tenure only holds if we do not regard a previous apprenticeship as tenure.
} 
wage reductions. Finally, we add workers' wage residual estimated from a Mincerian wage regression including several worker characteristics and firm fixed effects. This allows us to test whether firms selectively reduce wages in order to lower wage dispersion among similar workers as suggested by fairness considerations, or whether they exempt high-performers from wage cuts to prevent them from reducing effort or leaving the firm.

\section{Data}

To investigate individual differences in the exposure to real wage cuts, this paper uses seven waves of the German linked employer-employee data set of the Institute for Employment Research, the LIAB cross-sectional model, comprising the years 2000-2006. ${ }^{8}$ The LIAB combines a yearly survey of the same plants (not companies) with administrative data coming from the notification procedure of the German social insurance system (for details on the data, see Alda et al., 2005, or Jacobebbinghaus and Alda, 2007). While the plant survey includes information on plant size, sector, industrial relations, profitability, and workforce composition, the administrative data contains information on workers' gross daily real wage (deflated by the consumer price index), age, sex, nationality, schooling, and professional education at the 30th of June of each year. On average, more than 90 per cent of the workers in each plant who are covered by the social security system can be identified in the data. Due to the panel structure of the data set and the richness of the information contained, it is possible to both observe workers' professional career and their wage development as well as the characteristics of workers and their employers rendering the LIAB especially suitable for our purpose.

That said, we should make clear that our data set has three limitations important to our analysis (also compare Knoppik and Beissinger, 2003; Dustmann and Schönberg, 2009;

\footnotetext{
8 This is an interesting period with boom and bust phases starting with a high increase in real GDP of more than three percent in 2000, a decline to minus 0.2 percent in 2003 and a recovery to a growth of real GDP of two and an half percent in 2006.
} 
Gürtzgen, 2014). First, the start of employment relationships is left-censored at 1st January 1975 for workers in Western Germany and 1st January 1992 for workers in Eastern Germany because the notification procedure of the social security system that produces our individual data was not in place before these dates in the respective part of Germany. We will show below that tenure and experience have an important impact on the incidence of wage reductions (Anger, 2011). Therefore it is important to have no employees without precise tenure or experience information in our sample of young employees in their first job. Second, wages are top-coded at the social security contribution ceiling. The average share of employees with censored observations is around 15 percent. In several papers, the censored observations are imputed using observable characteristics. We know, however, that wage censoring is not random and clustered at older, higher tenured and better educated employees. Many employees in addition have censored wage observations in several years after each other. This means however that the wage changes might be calculated on the basis of two imputed wages whose information basis for the imputation only changed with respect to tenure and experience from year to year. The problem of imputed wages is greatly reduced in our sample of young employees that only entails censored wage observations for 4.6 per cent of workers (also see Dustmann and Schönberg, 2009 who use a similar argumentation for reducing their sample to young employees). We accordingly exclude these individuals from our analysis.

A third limitation of our data set is that we observe daily gross wages rather than hourly wage rates ${ }^{9}$ and detailed information on working hours is missing. We just observe a qualitative measure distinguishing full-time and two sorts of part-time employment. For this reason, we restrict our analysis to individuals working full-time hours, for whom daily gross wages are comparable. For the interpretation of our following results, it is thus important to bear in mind that cuts in real daily wages may occur due to a fall in the wage rate or due to reduced (paid or

9 Bonus payments are included in the hourly wages, however. This is important because bonus payments might vary during the economic cycle (Anger, 2011). 
unpaid) working hours (Anger, 2011). We argue, though, that this should not render our insights uninformative, as from a worker's point of view it is total real income that matters most, rather than the real hourly wage rate.

A comparison of our sample of young workers in their first job for a maximum of five years shows that young workers of course earn somewhat less, are more female and foreign born and more highly or low educated. They work more frequently in firms smaller firms with less labour representation and collective bargaining. Interestingly, the share of younger employees with wage reductions is not much smaller than in the full sample - this is in contrast to findings by Du Caju et al. (2012b) who report stronger wage insurance for younger employees.

\section{Econometric Approach}

In a first step, we analyse the incidence of a real wage reduction of five per cent or more relative to the previous year for those workers who stay with the same plant using a linear probability model. ${ }^{10}$ As individual covariates, we include (i) individual characteristics, (ii) interactions of these characteristics with the share of the plant's workers experiencing a real wage cut, and (iii) interactions of these characteristics with the share of other workers of the same characteristics in the plant's workforce. The inclusion of interactions of individual characteristics and the share of workers with a real wage cut allows us to investigate whether groups of workers with certain characteristics are disproportionally subject to wage reductions if the number of those affected increases. Moreover, adding interactions of individual characteristics with the share of other workers of the same characteristics enables us to analyse whether groups of workers forming a

10 Note that fitting probit models (without plant fixed effects) rather than linear probability models yields very similar results. The same holds when estimating complementary log-log models, which take into account that a real wage cut by five per cent or more is a quite rare event. Yet, estimating these non-linear binary response models does not allow us to include plant fixed effects in further analyses due to the incidental parameter problem, so that we stick to linear models in the following. 
small block of the plant's employment and labour costs are less often subject to wage cuts, i.e. the "importance of being unimportant" hypothesis. Note that all interaction terms (the shares of workers with certain characteristics and of workers hit by a wage reduction) are centred around their sample means. Hence, the slope coefficient for a certain characteristic can be interpreted as the partial effect for the average worker.

Following our theoretical considerations in Section 2, individual characteristics included are groups of education and tenure dummies. ${ }^{11}$ We further add a sex dummy and a dummy for German nationality as controls. Plant characteristics included are the shares of workers with the very same characteristics in the plant's workforce, the share of workers with a real wage reduction, the share of workers in their first jobs, a group of dummy variables capturing the plant's industrial relation regime (i.e. the existence of collective agreements either at sector or at firm level as well as works council existence), the percentage change in the plant's employment, a dummy for a good profit situation, a dummy indicating that management expects future employment decreases, groups of plant size as well as sector dummies, and a dummy for location in Eastern Germany. For descriptive statistics of key variables, see Table 1.

In a second step, we add plant fixed effects to our model and drop those plant covariates that are (almost) time-invariant such as sector dummies or the variables capturing the plant's industrial relations regime. Doing so rinses out permanent differences in plants’ wage policies that may not be fully captured by our plant covariates and thus bases our insights on a firmer footing.

In a final step, we add workers' wage residual estimated from an extended Mincerian

11 We distinguish workers with three levels of education: low-skilled, medium-skilled (i.e. with an occupational degree), and high-skilled (i.e. with an academic degree) workers. Note again that in our sample of young workers in their first jobs tenure equals experience. Note further that we control for education and tenure years for young employees in their first job. Therefore, age dummies are highly correlated with the other covariates and we do not include them as regressors. 
wage regression for the previous year that includes several individual characteristics and a plant fixed effect as regressors to our wage reduction model. ${ }^{12}$ The idea for this extension is that the wage residual can serve as a measure of individual performance or a specific value of the worker to the plant, both of which are unobservable for the researcher and result in a higher wage for this worker compared to his or her peer group of workers with the same observed characteristics. Since a plant fixed effect is included in the wage equation used to estimate the wage residual, it captures individual wage differences caused by unobserved individual characteristics given the plant's wage policy. The inclusion of the wage residual thus allows us to test whether employers exempt high-performance workers, i.e. those with a high wage residual, from wage cuts to prevent them from reducing their effort or leaving the plant as predicted by several strands of efficiency wage theory, or rather implement wage cuts in such a way that wage dispersion among peers is reduced as suggested by fairness considerations.

As a robustness check, we also calculate differences between employee groups for nominal wage reductions instead of real wage reductions of more than five percent. Differences in the incidence of real and nominal wage cuts are a major theme in the previous wage rigidity literature (compare for example Du Caju, 2012b), we do not expect differences in the selectivity of wage cuts when we reduce the barrier needed for our definition of wage cuts to nominal wage cuts.

\section{Results}

\subsection{Determinants of a Real Wage Reduction}

As discussed in the previous section, Table 2 shows the results from fitting linear models for individuals' probability of being hit by a real wage reduction of 5 per cent or more comprising

12 Further details on the specification of the wage equation are given in Section 5. 
several worker and plant characteristics (Model 1), plant fixed effects (Model 2), and the wage residual estimated from an extended Mincerian wage regression (Model 3). As can be seen from Model 1 in Table 2, we find strong evidence of selective real wage cuts. In line with earlier findings (Campbell, 1997; Kahn, 1997; Böckerman et al., 2007; Du Caju et al. 2012b), mediumskilled (high-skilled) workers have a 3.0 (1.6) percentage points lower probability of being hit by a real wage reduction than low-skilled workers (with the difference of the two effects not being statistically significant at the 10 per cent level). Whereas the effect for high-skilled workers is only statistically significant at the 10 per cent level, both effects are significant from an economic point of view, as only 13 per cent of workers experience real wage cuts in our sample of job starters (see Table 1). Furthermore, German and female workers are less often hit by real wage reductions. Du Caju et al. (2012b) do not find differences between the genders this may be an artefact however because they just split their samples according to one worker characteristics dimensions and therefore cannot simultaneously take into account that women differ from men with respect to qualification and tenure. In addition, the risk of being subject to a wage reduction is significantly lower for workers with low tenure. ${ }^{13}$ Previous empirical literature shows that the incidence of wage rigidity increases over the life cycle comparing 10 year age groups (Du Caju et al., 2012b). We find that this process already starts during the first tenure years. Yet interestingly, plants with a high share of low-tenure workers (two or less years of tenure) more often (have to) resort to real wage cuts. One reading of this finding is that plants that recently have expanded their workforce avoid firing these new hires when being forced to reduce their labour costs and cut wages instead - with the burden of wage reductions being shouldered by all of the plants' employees rather than by the newly hired exclusively.

13 One may wonder whether the positive impact of tenure on the risk of a real wage cut is the result of just considering workers with at most five years of tenure and reverses for more tenured workers. As a check of robustness we therefore redo our analysis for the larger sample of workers with at most ten years of tenure (again in their first job). As can be seen from Table A.2, which reports the coefficients for the tenure dummies only because those of other regressors are almost the same, this does not change our results. 
Unsurprisingly, we also find that the share of the plant's workers affected by a real wage reduction increases the individual probability of a wage cut. As can be seen from the coefficient of the share of workers with a real wage reduction, the partial effect for the reference group of non-German, male, and low-skilled workers with two years of tenure is clearly below unity, so that this group is less than proportionally hit by wage reductions. Adding the interaction effects of the share of those affected and the respective individual characteristics, we see that nonGerman, male, and low-skilled workers with three or four years of tenure are nearly proportionally hit by real wage reductions, whereas those with five years of tenure are more than proportionally subject to wage cuts. Given the large positive interaction effect for highskilled workers, all subgroups of workers with an academic degree are less than proportionally hit by wage reductions. As a consequence, real wage cuts seem to be highly selective with workers' skills and tenure being two crucial dimensions.

There is only slight evidence in line with the "importance of being unimportant" hypothesis stating that employers are more prone to selectively reduce wages for groups of workers who form a large fraction of the plant's workforce, as this arguably has a big impact on overall labour costs. We find that the share of workers with a certain characteristic in the firm's workforce, say three years of tenure, increases the individual risk of workers with the very same characteristic, viz. three years of tenure, to experience a wage reduction. ${ }^{14}$ Yet, these positive effects are generally not statistically significant, with some few exceptions such as medium-skilled workers or those with three years of tenure, and of modest size.

Turning to plant characteristics, we find that working for a plant covered by a collective agreement at sector level significantly decreases the likelihood of facing a real wage reduction (see also Devereux and Hart, 2006; Du Caju et al., 2012a), whereas neither the profit situation nor managers’ expectations about future employment changes have a significant impact. What 14 A positive interaction effect between the incidence of real wage cuts for females and their share in the
workforce is also found by Böckerman et al. (2007) in some of their models. 
is more, small plants resort to wage cuts more often than large plants (see also Böckerman et al., 2007; Du Caju et al., 2012b) as do Eastern German compared to Western German plants, which is clearly in line with our expectations. ${ }^{15}$

Adding plant fixed effects to the model does not change the picture (see Model 2 in Table 2). Our findings are thus not driven by unobserved differences in plants' time-invariant wage policies. In particular, all coefficients of individual characteristics are of similar magnitude as before, so that we are still left with strong evidence of highly selective wage cuts.

\subsection{Including Workers' Wage Residual}

Further including the wage residual estimated from an extended Mincerian wage regression for the previous year provides additional insights (see Model 3 in Table 2). As regressors to the wage equation we include a group of education dummies, a sex dummy, a dummy for German nationality, age (linearly and quadratic), tenure (linearly and quadratic), a group of dummy variables capturing the tenure in the previous job, a dummy variable indicating whether this job is the individual's first one, and a plant fixed effect. Table A1 in the appendix exemplarily reports the estimates for the year 2000. The very same model has been estimated for the years 2001-2006 with estimated coefficients being very similar to those reported for the year 2000 . Note that in these regressions observations for all full-time employed workers are included in order to consider plants' entire workforce, with top-coded wages being multiply imputed according to the method proposed by Addison et al. (2010). ${ }^{16}$

While including the wage residual to the model does not change much for the other variables included, we find that workers with a higher wage residual face a significantly lower

15 Note that running separate regressions for workers employed by Western and Eastern German plants does not change our insights.

16 Our results remain virtually unchanged when estimating individuals' wage residuals from (i) a joint wage regression for all years, (ii) yearly wage regressions excluding plant fixed effects, or (iii) yearly wage regressions excluding individuals with top-coded wages. 
probability of a real wage cut. Earning 10 per cent more than one's peers (i.e. other workers in the same plant with the very same individual characteristics) decreases the probability of a real wage cut by about 2.8 per cent on average. ${ }^{17}$ In the light of our discussion in Section 2, we interpret this finding as an indication that plants selectively spare high-performance workers from real wage cuts, thereby avoiding increased turnover and/or decreased effort of this crucial group of workers. Whereas this finding is in line with theoretical considerations relying on nonfairness efficiency wage and insider-outsider models, it is clearly at odds with fairness considerations pressing employers to use wage cuts in such a way to reduce wage dispersion among peers. ${ }^{18}$

According to our hypothesis, selectivity is comparable for real and nominal wage reductions. We present our preferred Model 3 from Table 2 with nominal wage reductions as dependent variable in Table A3 in the Appendix. Also replication of the more parsimonious models 1 and 2 in Table 3 with nominal wage rigidities leads to more or less the same results.

\subsection{Heterogeneities by Industrial Relations}

Up to now, we have controlled for industrial relations either by a group of industrial relations dummies or a plant fixed effect and thereby have restricted the individual and plant characteristics to show the same impact on individuals’ probability of being hit by a real wage reduction in plants with different industrial relations regimes. Yet, the existence of collective agreements or works councils may affect employers’ ability to engage in selective wage cuts.

17 As the wage residual is estimated from a wage equation for the previous year, one might argue that a positive wage residual just reflects above-average working hours, say, because of working overtime in that year, and therefore is likely to be reversed in the current year. Clearly, this would cause the residual to have a positive impact on the wage reduction probability rather than a negative which is found here. While we cannot rule out that the wage residual indeed reflects such working hours fluctuations, the positive impact found would thus be even more pronounced if these fluctuations were absent. Therefore, our conclusions are not driven by this point.

18 We also checked whether the effect of the wage residual is symmetric or differs for positive and negative residuals. We found a somewhat weaker effect for positive than for negative residuals. This did not change our results, however. 
The subgroups of workers employed by plants bound by collective agreements or having a works council may therefore show different selectivity patterns in wage cuts than those found when pooling all plants. ${ }^{19}$ To check this, we repeat our analysis for workers employed by three subgroups of plants: (i) plants covered by a collective agreement at sector level, (ii) plants bound by an agreement at firm level, and (iii) plants with a works council. As can be seen from Table 3, which reports linear models for the individual wage reduction probability of these three groups of workers (analogous to Model 3 in Table 2), our findings for all firms also hold in these three subgroups, with only little differences across groups. ${ }^{20} \mathrm{All}$ in all, we thus find clear and robust evidence that employers make use of selective real wage cuts. ${ }^{21}$

\section{Conclusions}

In this paper, we have investigated whether employers who (have to) reduce real wages do so in a selective manner. Using German linked employer-employee panel data for the homogenous group of young workers in the first five years of their first job, we fitted linear models for individuals' probability of experiencing a real wage cut of at least five percent including plant fixed effects that control for permanent differences in plants' wage policies. We find clear evidence that firms resort to selective wage reductions in line with insider-outsider

19 Note, however, that in our period of observation a growing number of collective agreements include so-called opening clauses and, in the case of firm-level contracts, company-level pacts for employment and competitiveness (e.g. Bellmann et al., 2008). These give bargaining partners the opportunity to cut wages in a similar manner as in individual contracts provided certain requirements stipulated in the clauses are met.

20 In further regressions, we also redid this analysis for even finer subgroups of plants such as plants with both a works council and a collective agreement at sector level. This did not change our findings.

21 Obviously, (selective) wage cuts are only one alternative for employers to decrease labour costs. Another alternative is to rely on (selective) layoffs. To see whether plants resort to selective layoffs and which groups of workers are more likely to be laid off, we estimated a linear model for the individual probability of job termination mirroring Model 3 from Table 2. As can be seen from Table A.4, several regressors have an analogous impact as in the wage reduction equation such as workers' wage residual, skills, and nationality, thereby further substantiating our findings, whereas covariates such as tenure and sex point in the opposite direction. These findings might be a first indication that some employee groups such as higher educated employees and employees with unobservable positive characteristics are strongly shielded against negative shocks both in terms of wage and employment stability. Other workers such as females or employees in their first and second year of employment have a lower risk to suffer wage reductions. However, this comes at the cost of a higher employment termination risk. 
and several branches of efficiency wage theory, but in contrast to some recent contributions discarding selective wage reductions and stressing fairness considerations instead.

Medium-skilled and high-skilled workers are less likely to face a real wage reduction than low-skilled workers. Especially high-skilled workers are less than proportionally hit by wage cuts. The same holds for workers who have just recently been hired. We find almost no evidence for what we termed the "importance of being unimportant" hypothesis. That is, workers' individual risk of a real wage reduction seems not to be higher if the share of workers with the same individual characteristics is higher in the workforce, so that wage reductions for this very group are likely to have a big impact on the employer's total labour costs. Adding workers' wage residual estimated from an extended Mincerian wage regression for the previous year as a measure of unobserved worker performance, we further find that workers with a higher residual have a significantly lower incidence of real wage cuts. This finding is clearly in line with bargaining and several branches of efficiency wage theory, it is at odds, however, with fairness considerations pressing employers to selectively reduce wages such that wage dispersion among peers is reduced. We thus conclude that real wage reductions, though rare in general, are specifically aimed at those groups of workers who are less crucial to firm performance. 


\section{References}

Addison, J., P. Teixeira, and T. Zwick (2010), "German works councils and the anatomy of wages”, Industrial and Labor Relations Review, 63(2): 247-260.

Agell, J. and H. Bennmarker (2007), “Wage incentives and wage rigidity: a representative view from within”, Labour Economics, 14(3): 347-369.

Akerlof, G.A. (1982), “Labor contracts as partial gift exchange”, Quarterly Journal of Economics, 97(4): 543-569.

Akerlof, G.A. and J.L. Yellen (1990), “The fair wage-effort hypothesis and unemployment”, Quarterly Journal of Economics, 105(2): 255-283.

Alda, H., S. Bender, and H. Gartner (2005), “The linked employer-employee dataset created from the IAB Establishment Panel and the process-produced data of the IAB (LIAB)", Schmollers Jahrbuch, 125(2): 327-336.

Anger, S. (2011), “The cyclicality of effective wages within employer-employee matches in a rigid labor market”, Labour Economics, 18(6): 786-797.

Arai, M. (2003), "Wages, profits, and capital intensity: evidence from matched worker-firm data”, Journal of Labor Economics, 21(3): 593-618.

Azariadis, C. (1975), “Implicit contracts and underemployment equilibria”, Journal of Political Economy, 83(6): 1183-1202.

Babecký, J., P. Du Caju, T. Kosma, M. Lawless, J. Messina, and T. Rõõm (2010), “Downward nominal and real wage rigidity: Survey evidence from European firms”, Scandinavian Journal of Economics, 112(4): 884-910.

Baily, M.N. (1974), “Wages and employment under uncertain demand”, Review of Economic Studies, 41(1): 37-50.

Bellmann, L., Gerlach, K., and Meyer, W. (2008), “Company-level pacts for employment”, Journal of Economics and Statistics, 228(5+6): 533-553.

Bewley, T.F. (1999), Why Wages Don't Fall During a Recession, Cambridge, MA: Harvard University Press.

Blinder, A. and D. Choi (1990), “A shred of evidence on theories of wage stickiness”, Quarterly Journal of Economics, 105(4): 1003-1015.

Böckerman P., S. Laaksonen, and J. Vainiomäki (2007), “Who bears the burden of wage cuts? Evidence from Finland during the 1990s”, International Journal of Manpower, 28(2): $100-121$. 
Campbell, C.M. (1997), “The variation in wage rigidity by occupation and union status in the US”, Oxford Bulletin of Economics and Statistics 59(1): 133-147.

Campbell, C.M. and K.S. Kamlani (1997), "The reasons for wage rigidity: Evidence from a survey of firms”, Quarterly Journal of Economics, 112(3): 759-789.

Cardoso, A. R. and M. Portela (2009), “Micro foundations for wage flexibility: Wage insurance at the firm level”, Scandinavian Journal of Economics 111(1), 29-50.

Cohn, A., E. Fehr, B. Herrmann, and F. Schneider (2011), Social Comparison in the Workplace: Evidence from a Field Experiment, IZA Discussion Paper no. 5550, Institute for the Study of Labor: Bonn.

Cornelißen, T. and O. Hübler (2008), “Downward wage rigidity and job mobility”, Empirical Economics, 34(2): 205-230.

Devereux, P. (2001), “The cyclicality of real wages within employer-employee matches”, Industrial and Labor Relations Review 54(4): 835-850.

Devereux, P. and R. Hart (2006), "Real wage cyclicality of job stayers, within-company job movers, and between-company job movers”, Industrial and Labor Relations Review 60(1): 105-119.

Dickens, W.T., L. Götte, E.L. Groshen, S. Holden, J. Messina, M.E. Schweitzer, J. Turunen, and M.E. Ward (2007), “How wages change: micro evidence from the International Wage Flexibility Project”, Journal of Economic Perspectives, 21(2), 195-214.

Dickens, W.T. and L. Götte (2006), “Estimating wage rigidity for the international wage flexibility project”, mimeo, Brookings Institution.

Du Caju, P., C. Fuss, and L. Wintr (2012a), “Sectoral differences in downward real wage rigidity: workforce composition, institutions, technology and competition”, Journal for Labour Market Research, 45(1): 7-22.

Du Caju, P., C. Fuss, and L. Wintr (2012b), “Downward wage rigidity for different workers and firms”, Brussels Economic Review, 55(1): 5-32.

Du Caju, P., T. Kosma, M. Lawless, J. Messina, and T. Room (2013), Why firms avoid cutting wages: Survey evidence from European firms, Eesti Pank working paper series, 2/2013, Tallinn.

Dustmann, C. and U. Schönberg (2009), “Training and union wages”, Review of Economics and Statistics, 91(2): 363-376.

Fehr, E. and L. Götte (2005), "Robustness and real consequences of nominal wage rigidity”, Journal of Monetary Economics, 52(4): 779-804. 
Flinn, C.J. (1986), "Wages and job mobility of young workers”, Journal of Political Economy, 94(3): S88-S110.

Franz, W. and F. Pfeiffer (2006), "Reasons for wage rigidity in Germany”, Labour, 20(2): 255284.

Gartner, H., T. Schank, and C. Schnabel (2013), “Wage cyclicality under different regimes of industrial relations”, Industrial Relations, 52(2): 516-540.

Gürtzgen, N. (2009), “Rent-sharing and collective bargaining coverage: evidence from linked employer-employee data”, Scandinavian Journal of Economics, 111(2): 323-349.

Gürtzgen, N. (2014), “Wage Insurance within German firms: Do institutions matter?”, Journal of the Royal Statistical Society: Series A, 117(2): 345-369.

Guiso, L., L. Pistaferri, and F. Schivardi (2005), “Insurance within the firm”, Journal of Political Economy 113: 1054-1087.

Jacobebbinghaus, P. and H. Alda (2007), LIAB-Datenhandbuch: Version 2.0, Nuremberg: Institute for Employment Research.

Retrieved 30/07/2014 from http://doku.iab.de/fdz/reporte/2007/DR_02-07.pdf

Holden, S. (1994), "Wage bargaining and nominal rigidities”, European Economic Review, 38(5): 1021-1039.

Howitt, P. (2002), “Looking inside the labor market: A review article”, Journal of Economic Literature, 40(1): 125-138.

Kahn, S. (1997), “Evidence of nominal wage stickiness from microdata”, American Economic Review 87(5): 997-1008.

Kim, H., E. Maug, and C. Schneider (2014), Labor Representation in Governance as an Insurance Mechanism, ECGI Finance Working Paper 411/2014, Mannheim.

Knoppik, C. and T. Beissinger (2003), "How Rigid are Nominal Wages? Evidence and Implications for Germany”, Scandinavian Journal of Economics 105(4): 619-641.

Kube, S., M.A. Maréchal, and C. Puppe (2013), “Do wage cuts damage work morale? Evidence from a natural field experiment”, Journal of the European Economic Association, 11(4): 853-870.

Lazear, E. (1979), “Why is there mandatory retirement?”, Journal of Political Economy, 87(6): 1241-1264.

Lee, D. and N.G. Rupp (2007), "Retracting a gift: How does employee effort respond to wage reductions?”, Journal of Labor Economics, 25(4): 725-761. 
Lindbeck, A. and D.J. Snower (1988), “Cooperation, harassment, and involuntary unemployment: An insider-outsider approach”, American Economic Review, 78(1): 167-188.

Malcomson, J.M. (1997), “Contracts, hold-up, and labor markets”, Journal of Economic Literature, 35(4): 1916-1957.

Oi, W.Y. and T.L. Idson (1999), "Firm size and wages”, in O.C. Ashenfelter and D.E. Card (eds.), Handbook of Labor Economics, vol. 3B, pp. 2165-2214, Amsterdam: Elsevier.

Shapiro, C. and J.E. Stiglitz (1984), "Equilibrium unemployment as a worker discipline device”, American Economic Review, 74(3): 433-444.

Stiglitz, J.E. (1974), “Alternative theories of wage determination and unemployment in LDCs: the labor turnover model”, Quarterly Journal of Economics, 88(2): 194-227.

Stüber, H. (2013), Wage Rigidity in Germany, IAB-Bibliothek No. 340, Bielefeld: W. Bertelsmann Verlag.

Weiss, A. (1980), “Job queues and layoffs in labor markets with flexible wages”, Journal of Political Economy, 88(3): 526-538.

Yellen, J. (1984), “Efficiency wage models of unemployment”, American Economic Review (Papers and Proceedings), 74(2): 200-205.

Zwick, T. (2011), "Why training older employees is less effective”, ZEW Discussion Paper No. 11-046, Mannheim, forthcoming in International Journal of Manpower 
Table 1: $\quad$ Selected descriptive statistics (means)

\begin{tabular}{lcr}
\hline \hline & Full sample & $\begin{array}{c}\text { Sample of young } \\
\text { workers in first job }\end{array}$ \\
\hline Share of workers with real wage reduction larger than 5 per cent & 0.134 & 0.131 \\
Share of workers with nominal wage reduction & 0.207 & 0.195 \\
Low-skilled (no occupational degree) & 0.131 & 0.235 \\
Medium-skilled (occupational degree) & 0.684 & 0.521 \\
High-skilled (academic degree) & 0.136 & 0.254 \\
Female & 0.267 & 0.394 \\
German & 0.923 & 0.806 \\
Share of workers with tenure no more than 5 years & 0.348 & 1.000 \\
Share of workers in first job & 0.197 & 1.000 \\
Log wage & 4.573 & 4.230 \\
Yearly change in log real wages & 0.027 & 0.023 \\
Relative employment change & 0.007 & 0.009 \\
Expected employment reduction & 0.373 & 0.354 \\
Works council & 0.866 & 0.818 \\
Collective bargaining at sector level & 0.722 & 0.694 \\
Collective bargaining at firm level & 0.137 & 0.114 \\
Good profit situation & 0.199 & 0.277 \\
Plant size 1-20 & 0.028 & 0.036 \\
Plant size 21-200 & 0.195 & 0.203 \\
Plant size 201-500 & 0.186 & 0.186 \\
Plant size 501-2000 & 0.294 & 0.310 \\
Plant size larger than 2000 & 0.297 & 0.255 \\
East Germany & 0.178 & 0.169 \\
\hline \hline
\end{tabular}

Notes: The data set used is the LIAB cross-sectional model, waves 2000-2006. 
Table 2: Individual probability of facing a real wage reduction

\begin{tabular}{|c|c|c|c|c|c|c|}
\hline \multirow{2}{*}{$\begin{array}{l}\text { Regressand: dummy for real wage reduction } \\
\text { Regressors: }\end{array}$} & \multicolumn{2}{|c|}{ Model 1: OLS } & \multicolumn{2}{|c|}{ Model 2: plant FE } & \multicolumn{2}{|c|}{ Model 3: plant FE } \\
\hline & Coef. & SE & Coef. & SE & Coef. & SE \\
\hline Wage residual in previous year & & & & & $-0.277 * *$ & $(0.011)$ \\
\hline Medium-skilled (occupational degree) & $-0.030 * *$ & $(0.005)$ & $-0.031 * *$ & $(0.005)$ & $-0.048 * *$ & $(0.005)$ \\
\hline High-skilled (academic degree) & -0.016 & $(0.008)$ & $-0.018 *$ & $(0.008)$ & $-0.042 * *$ & $(0.009)$ \\
\hline Female & $-0.024 * *$ & $(0.004)$ & $-0.023 * *$ & $(0.004)$ & $-0.012 * *$ & $(0.004)$ \\
\hline German & $-0.054 * *$ & $(0.006)$ & $-0.056 * *$ & $(0.006)$ & $-0.078 * *$ & $(0.006)$ \\
\hline Tenure 3 years & $0.051 * *$ & $(0.005)$ & $0.054 * *$ & $(0.005)$ & $0.061 * *$ & $(0.005)$ \\
\hline Tenure 4 years & $0.122 * *$ & $(0.005)$ & $0.125 * *$ & $(0.005)$ & $0.135 * *$ & $(0.005)$ \\
\hline Tenure 5 years & $0.132 * *$ & $(0.006)$ & $0.135 * *$ & $(0.006)$ & $0.145 * *$ & $(0.006)$ \\
\hline Share of workers with real wage reduction & $0.802 * *$ & $(0.024)$ & $0.753 * *$ & $(0.027)$ & $0.747 * *$ & $(0.027)$ \\
\hline Relative employment change & $-0.014 *$ & $(0.007)$ & -0.003 & $(0.007)$ & -0.004 & $(0.007)$ \\
\hline Share of medium-skilled workers & -0.032 & $(0.018)$ & 0.021 & $(0.061)$ & 0.008 & $(0.062)$ \\
\hline Share of high-skilled workers & $-0.114 * *$ & $(0.027)$ & -0.102 & $(0.109)$ & -0.092 & $(0.108)$ \\
\hline Share of female workers & 0.010 & $(0.017)$ & 0.120 & $(0.083)$ & 0.146 & $(0.082)$ \\
\hline Share of German workers & 0.039 & $(0.031)$ & 0.105 & $(0.110)$ & 0.086 & $(0.109)$ \\
\hline Share of workers with 1 year tenure & $0.147 * *$ & $(0.021)$ & 0.063 & $(0.043)$ & $0.100 *$ & $(0.043)$ \\
\hline Share of workers with 2 years tenure & $0.161 * *$ & $(0.029)$ & 0.076 & $(0.045)$ & 0.089 & $(0.046)$ \\
\hline Share of workers with 3 years tenure & 0.045 & $(0.027)$ & -0.010 & $(0.035)$ & -0.007 & $(0.036)$ \\
\hline Share of workers with 4 years tenure & -0.013 & $(0.026)$ & -0.022 & $(0.025)$ & -0.021 & $(0.028)$ \\
\hline Share of workers with 5 years tenure & 0.024 & $(0.024)$ & 0.029 & $(0.024)$ & 0.032 & $(0.025)$ \\
\hline Share of workers with first job & 0.016 & $(0.015)$ & 0.074 & $(0.081)$ & 0.061 & $(0.078)$ \\
\hline Works council & -0.004 & $(0.006)$ & & & & \\
\hline Collective bargaining at sector level & $-0.024^{* *}$ & $(0.006)$ & & & & \\
\hline Collective bargaining at firm level & -0.002 & $(0.012)$ & & & & \\
\hline Expected employment decrease & 0.037 & $(0.056)$ & $0.197 *$ & $(0.094)$ & $0.219 * *$ & $(0.083)$ \\
\hline Good profit situation & -0.008 & $(0.005)$ & -0.009 & $(0.006)$ & -0.008 & $(0.006)$ \\
\hline Plant size $1-20$ & $0.033 * *$ & $(0.010)$ & -0.008 & $(0.036)$ & -0.012 & $(0.036)$ \\
\hline Plant size $21-200$ & $0.014 * *$ & $(0.005)$ & 0.006 & $(0.017)$ & 0.000 & $(0.017)$ \\
\hline Plant size 501-2000 & 0.006 & $(0.006)$ & -0.027 & $(0.016)$ & -0.027 & $(0.016)$ \\
\hline Plant size larger than 2000 & -0.011 & $(0.009)$ & -0.048 & $(0.029)$ & $-0.060 *$ & $(0.027)$ \\
\hline East Germany & $0.027 * *$ & $(0.006)$ & & & & \\
\hline Medium-skilled * share medium-skilled & $0.087 * *$ & $(0.030)$ & 0.067 & $(0.036)$ & 0.059 & $(0.038)$ \\
\hline High-skilled $*$ share high-skilled & $0.074 *$ & $(0.037)$ & 0.039 & $(0.042)$ & -0.000 & (0.043) \\
\hline Female $*$ share females & $0.065 * *$ & $(0.017)$ & $0.049 * *$ & $(0.017)$ & $0.033 *$ & $(0.017)$ \\
\hline German * share Germans & $-0.108 * *$ & $(0.035)$ & $-0.110 * *$ & $(0.039)$ & $-0.131 * *$ & $(0.045)$ \\
\hline Tenure 3 years $*$ share tenure 3 years & 0.068 & $(0.036)$ & 0.045 & $(0.042)$ & 0.029 & $(0.040)$ \\
\hline Tenure 4 years $*$ share tenure 4 years & 0.049 & $(0.039)$ & 0.054 & $(0.042)$ & 0.040 & $(0.047)$ \\
\hline Tenure 5 years $*$ share tenure 5 years & 0.022 & $(0.037)$ & 0.022 & $(0.041)$ & 0.007 & $(0.041)$ \\
\hline Wage residual * share real wage reduction & & & & & -0.018 & $(0.050)$ \\
\hline Medium-skilled * share real wage reduction & $-0.074 * *$ & $(0.019)$ & $-0.069 * *$ & $(0.022)$ & $-0.062 * *$ & $(0.021)$ \\
\hline High-skilled $*$ share wage reduction & $-0.216 * *$ & $(0.031)$ & $-0.183 * *$ & $(0.035)$ & $-0.178 * *$ & $(0.036)$ \\
\hline Female $*$ share wage reduction & $-0.047 * *$ & $(0.016)$ & $-0.057 * *$ & $(0.018)$ & $-0.059 * *$ & $(0.018)$ \\
\hline German * share wage reduction & $-0.061 *$ & $(0.024)$ & $-0.063 *$ & $(0.028)$ & $-0.062 *$ & $(0.027)$ \\
\hline Tenure 3 years $*$ share real wage reduction & $0.132 * *$ & $(0.020)$ & $0.141^{* *}$ & $(0.022)$ & $0.138 * *$ & $(0.021)$ \\
\hline Tenure 4 years $*$ share real wage reduction & $0.266 * *$ & $(0.020)$ & $0.298 * *$ & $(0.022)$ & $0.298 * *$ & $(0.022)$ \\
\hline Tenure 5 years $*$ share real wage reduction & $0.299 * *$ & $(0.021)$ & $0.331 * *$ & $(0.023)$ & $0.324 * *$ & $(0.023)$ \\
\hline Number of observations: 108,003 & $\mathrm{R}^{2}: 0$ & 163 & $\mathrm{R}^{2}$ (overall & 0.152 & $\mathrm{R}^{2}$ (overall & 0.161 \\
\hline $\begin{array}{l}\text { Notes: The data set used is the LIAB cross-sectio } \\
5 \text { years tenure are included. } * * / * \text { denotes statis } \\
\text { clustered at the plant level. Reference group: lc } \\
\text { employees with neither a works council nor a } \\
\text { dummies and a constant. In all interaction terms, } \\
\text { wage reduction are centred around their sample }\end{array}$ & odel, waves & $2000-2$ & Only worke & s in their & t job and witl & $\begin{array}{l}\text { at most } \\
\text { rrors are } \\
201-500 \\
\text { d } 6 \text { year } \\
\text { by a real }\end{array}$ \\
\hline
\end{tabular}


Table 3: Individual probability of facing a real wage reduction by industrial relations

\begin{tabular}{|c|c|c|c|c|c|c|}
\hline \multirow{2}{*}{$\begin{array}{l}\text { Regressand: dummy for real wage reduction } \\
\text { Regressors: }\end{array}$} & \multicolumn{2}{|c|}{$\begin{array}{l}\text { Collective agree- } \\
\text { ment at sector level }\end{array}$} & \multicolumn{2}{|c|}{$\begin{array}{l}\text { Collective agree- } \\
\text { ment at firm level }\end{array}$} & \multicolumn{2}{|c|}{ Works council } \\
\hline & Coef. & SE & Coef. & SE & Coef. & SE \\
\hline Wage residual in previous year & $-0.255 * *$ & $(0.013)$ & $-0.325 * *$ & $(0.030)$ & $-0.261 * *$ & $(0.012)$ \\
\hline Medium-skilled (occupational degree) & $-0.054 * *$ & $(0.007)$ & -0.027 & $(0.015)$ & $-0.050 * *$ & $(0.006)$ \\
\hline High-skilled (academic degree) & $-0.039 * *$ & $(0.011)$ & $-0.073 * *$ & $(0.019)$ & $-0.040 * *$ & $(0.010)$ \\
\hline Female & $-0.014 * *$ & $(0.005)$ & -0.013 & $(0.011)$ & $-0.015 * *$ & $(0.005)$ \\
\hline German & $-0.081 * *$ & $(0.007)$ & $-0.069 * *$ & $(0.012)$ & $-0.079 * *$ & $(0.006)$ \\
\hline Tenure 3 years & $0.056 * *$ & $(0.006)$ & $0.095 * *$ & $(0.015)$ & $0.061 * *$ & $(0.005)$ \\
\hline Tenure 4 years & $0.136 * *$ & $(0.006)$ & $0.149 * *$ & $(0.014)$ & $0.139 * *$ & $(0.006)$ \\
\hline Tenure 5 years & $0.146 * *$ & $(0.007)$ & $0.170 * *$ & $(0.016)$ & $0.151^{* *}$ & $(0.006)$ \\
\hline Share of workers with real wage reduction & $0.684 * *$ & $(0.033)$ & $0.737 * *$ & $(0.062)$ & $0.688 * *$ & $(0.031)$ \\
\hline Relative employment change & 0.005 & $(0.009)$ & $-0.026 * *$ & $(0.007)$ & -0.009 & $(0.007)$ \\
\hline Share of medium-skilled workers & 0.032 & $(0.091)$ & -0.045 & $(0.202)$ & -0.000 & $(0.085)$ \\
\hline Share of high-skilled workers & -0.115 & $(0.130)$ & -0.017 & $(0.283)$ & -0.116 & $(0.126)$ \\
\hline Share of female workers & 0.012 & $(0.108)$ & -0.418 & $(0.304)$ & 0.152 & $(0.122)$ \\
\hline Share of German workers & 0.039 & $(0.158)$ & 0.652 & $(0.591)$ & 0.106 & $(0.210)$ \\
\hline Share of workers with 1 year tenure & 0.074 & $(0.062)$ & 0.074 & $(0.137)$ & $0.115 *$ & $(0.058)$ \\
\hline Share of workers with 2 years tenure & -0.024 & $(0.067)$ & 0.152 & $(0.147)$ & 0.014 & $(0.067)$ \\
\hline Share of workers with 3 years tenure & -0.025 & $(0.046)$ & 0.059 & (0.109) & -0.034 & $(0.043)$ \\
\hline Share of workers with 4 years tenure & -0.042 & $(0.026)$ & 0.020 & $(0.084)$ & -0.045 & $(0.026)$ \\
\hline Share of workers with 5 years tenure & 0.022 & $(0.028)$ & -0.014 & $(0.088)$ & 0.029 & $(0.028)$ \\
\hline Share of workers with first job & -0.102 & $(0.102)$ & $-0-108$ & $(0.264)$ & 0.031 & $(0.116)$ \\
\hline Good profit situation & $-0.015 *$ & (0.007) & 0.004 & $(0.015)$ & -0.011 & $(0.006)$ \\
\hline Plant size $1-20$ & 0.010 & $(0.051)$ & 0.181 & $(0.207)$ & 0.114 & $(0.091)$ \\
\hline Plant size 21-200 & 0.021 & $(0.025)$ & -0.012 & $(0.040)$ & 0.012 & $(0.021)$ \\
\hline Plant size 501-2000 & -0.003 & $(0.021)$ & 0.001 & $(0.039)$ & -0.028 & $(0.018)$ \\
\hline Plant size larger than 2000 & -0.065 & $(0.033)$ & 0.059 & $(0.061)$ & $-0.059 *$ & $(0.029)$ \\
\hline Medium-skilled * share medium-skilled & $0.095 *$ & $(0.048)$ & -0.081 & $(0.073)$ & $0.086 *$ & $(0.044)$ \\
\hline High-skilled * share high-skilled & 0.012 & $(0.060)$ & 0.026 & $(0.097)$ & -0.003 & $(0.049)$ \\
\hline Female * share females & 0.018 & $(0.020)$ & $0.103 *$ & $(0.046)$ & $0.038 *$ & $(0.018)$ \\
\hline German * share Germans & $-0.128 *$ & $(0.054)$ & -0.173 & $(0.109)$ & $-0.131 *$ & $(0.051)$ \\
\hline Tenure 3 years * share tenure 3 years & 0.061 & $(0.053)$ & 0.153 & (0.139) & 0.021 & $(0.048)$ \\
\hline Tenure 4 years $*$ share tenure 4 years & 0.061 & $(0.054)$ & 0.045 & $(0.143)$ & 0.079 & $(0.052)$ \\
\hline Tenure 5 years $*$ share tenure 5 years & 0.013 & $(0.047)$ & 0.008 & (0.137) & 0.042 & $(0.050)$ \\
\hline Wage residual * share real wage reduction & -0.007 & $(0.061)$ & 0.154 & $(0.155)$ & 0.021 & $(0.061)$ \\
\hline Medium-skilled * share real wage reduction & $-0.056 *$ & $(0.029)$ & 0.064 & $(0.052)$ & -0.049 & $(0.026)$ \\
\hline High-skilled * share wage reduction & $-0.147 * *$ & $(0.046)$ & -0.087 & $(0.088)$ & $-0.147 * *$ & $(0.039)$ \\
\hline Female $*$ share wage reduction & $-0.082 * *$ & $(0.020)$ & $-0.133 *$ & $(0.051)$ & $-0.082 * *$ & $(0.021)$ \\
\hline German * share wage reduction & $-0.086 *$ & $(0.038)$ & $-0.130 * *$ & $(0.045)$ & $-0.081 * *$ & $(0.031)$ \\
\hline Tenure 3 years * share real wage reduction & $0.129 * *$ & $(0.027)$ & 0.223 & $(0.051)$ & $0.157 * *$ & $(0.025)$ \\
\hline Tenure 4 years * share real wage reduction & $0.311 * *$ & $(0.028)$ & 0.380 & (0.049) & $0.363 * *$ & $(0.025)$ \\
\hline Tenure 5 years * share real wage reduction & $0.363 * *$ & $(0.029)$ & 0.397 & $(0.049)$ & $0.402 * *$ & $(0.025)$ \\
\hline Number of observations & 74,9 & & 12,31 & & $88,2 \varepsilon$ & \\
\hline $\mathrm{R}^{2}$ (overall) & 0.1 & & 0.16 & & 0.13 & \\
\hline
\end{tabular}

Notes: The data set used is the LIAB cross-sectional model, waves 2000-2006. Only workers in their first job and with at most 5 years tenure are included. $* * / *$ denotes statistical significance at the 1/5 per cent level, where robust standard errors are clustered at the plant level. Reference group: low-skilled worker with 2 years of tenure working for a plant with 201-500 employees with neither a works council nor a collective agreement; further regressors included are 16 sector and 6 year dummies and a constant. All estimates include plant fixed effects and are thus comparable to Model 3 in Table 2. In all interaction terms, the shares of workers with certain characteristics and of workers hit by a real wage reduction are centred around their sample means. 


\section{Appendix}

Table A1: Wage regression including plant fixed effects for the year 2000

\begin{tabular}{lcl}
\hline \hline Regressand: log wage & \multicolumn{2}{c}{ Plant FE } \\
\hline Regressors: & Coef. & SE \\
\hline Medium-skilled (occupational degree) & $0.145^{* *}$ & $(0.004)$ \\
High-skilled (academic degree) & $0.551^{* *}$ & $(0.007)$ \\
Female & $-0.137^{* *}$ & $(0.002)$ \\
German & $0.045^{* *}$ & $(0.003)$ \\
Age & $0.021^{* *}$ & $(0.001)$ \\
Age squared/100 & $-0.020^{* *}$ & $(0.000)$ \\
Tenure & $0.018^{* *}$ & $(0.001)$ \\
Tenure squared/100 & $-0.035^{* *}$ & $(0.002)$ \\
Tenure before the job 2-5 years & $0.006^{* *}$ & $(0.002)$ \\
Tenure before the job 6-10 years & $0.023^{* *}$ & $(0.002)$ \\
Tenure before the job more than 10 years & $0.058^{* *}$ & $(0.003)$ \\
First job & 0.002 & $(0.002)$ \\
\hline Number of observations: 1,477,192 & $\mathrm{R}^{2}$ (overall): 0.357 \\
\hline \hline
\end{tabular}

Notes: The data set used is the LIAB cross-sectional model, waves 2000-2006. **/* denotes statistical significance at the 1/5 per cent level, where robust standard errors are clustered at the plant level. 
Table A2: Individual probability of facing a real wage reduction (10 years of tenure)

\begin{tabular}{|c|c|c|}
\hline \multirow{2}{*}{$\begin{array}{l}\text { Dependent variable: dummy for real wage reduction } \\
\text { Regressors: }\end{array}$} & \multicolumn{2}{|c|}{ Plant FE } \\
\hline & Coef. & SE \\
\hline Tenure 3 years & $0.060 * *$ & $(0.005)$ \\
\hline Tenure 4 years & $0.135^{* *}$ & $(0.005)$ \\
\hline Tenure 5 years & $0.145^{* *}$ & $(0.006)$ \\
\hline Tenure 6 years & $0.159 * *$ & $(0.006)$ \\
\hline Tenure 7 years & $0.181^{* *}$ & $(0.006)$ \\
\hline Tenure 8 years & $0.193^{* *}$ & $(0.006)$ \\
\hline Tenure 9 years & $0.201^{* *}$ & $(0.006)$ \\
\hline Tenure 10 years & $0.212 * *$ & $(0.006)$ \\
\hline Tenure 3 years $*$ share tenure 3 years & 0.023 & $(0.041)$ \\
\hline Tenure 4 years $*$ share tenure 4 years & 0.064 & $(0.043)$ \\
\hline Tenure 5 years $*$ share tenure 5 years & -0.000 & $(0.037)$ \\
\hline Tenure 6 years * share tenure 6 years & $0.075^{*}$ & $(0.037)$ \\
\hline Tenure 7 years $*$ share tenure 7 years & -0.007 & $(0.042)$ \\
\hline Tenure 8 years $*$ share tenure 8 years & $0.048 * *$ & $(0.013)$ \\
\hline Tenure 9 years $*$ share tenure 9 years & 0.025 & $(0.014)$ \\
\hline Tenure 10 years * share tenure 10 years & -0.031 & $(0.020)$ \\
\hline Tenure 3 years * share wage reduction & $0.135^{* *}$ & $(0.021)$ \\
\hline Tenure 4 years $*$ share wage reduction & $0.284^{* *}$ & $(0.022)$ \\
\hline Tenure 5 years $*$ share wage reduction & $0.315^{* *}$ & $(0.023)$ \\
\hline Tenure 6 years $*$ share wage reduction & $0.344^{* *}$ & $(0.022)$ \\
\hline Tenure 7 years $*$ share wage reduction & $0.395^{* *}$ & $(0.021)$ \\
\hline Tenure 8 years $*$ share wage reduction & $0.427 * *$ & $(0.023)$ \\
\hline Tenure 9 years * share wage reduction & $0.405^{* *}$ & $(0.026)$ \\
\hline Tenure 10 years * share wage reduction & $0.454^{* *}$ & $(0.026)$ \\
\hline Number of observations: 417,898 & \multicolumn{2}{|c|}{$\mathrm{R}^{2}$ (overall): 0.218} \\
\hline
\end{tabular}

Notes: The data set used is the LIAB cross-sectional model, waves 2000-2006. Only workers in their first job and with at most 10 years tenure are included. $* * * *$ denotes statistical significance at the $1 / 5$ per cent level, where robust standard errors are clustered at the plant level. Reference group: low-skilled worker with 2 years of tenure working for a plant with 201-500 employees with neither a works council nor a collective agreement; further regressors included are those from Model 3 in Table 2. In all interaction terms, the shares of workers with certain characteristics and of workers hit by a real wage reduction are centred around their sample means. 
Table A3: Individual probability of facing a nominal wage reduction

\begin{tabular}{|c|c|c|}
\hline Regressand: dummy for nominal wage reduction & Model 3: pl & at FE \\
\hline Regressors: & Coef. & SE \\
\hline Wage residual in previous year & $-0.351 * *$ & $(0.017)$ \\
\hline Medium-skilled (occupational degree) & $-0.037 *$ & $(0.003)$ \\
\hline High-skilled (academic degree) & $-0.094 * *$ & $(0.007)$ \\
\hline Female & $-0.008 *$ & $(0.008)$ \\
\hline German & $-0.034 * *$ & $(0.004)$ \\
\hline Tenure 3 years & $0.061 * *$ & $(0.005)$ \\
\hline Tenure 4 years & $0.135 * *$ & $(0.005)$ \\
\hline Tenure 5 years & $0.145 * *$ & $(0.006)$ \\
\hline Share of workers with nominal wage reduction & $0.617 * *$ & $(0.027)$ \\
\hline Relative employment change & 0.004 & $(0.006)$ \\
\hline Share of medium-skilled workers & 0.085 & $(0.058)$ \\
\hline Share of high-skilled workers & -0.107 & $(0.098)$ \\
\hline Share of female workers & 0.148 & $(0.075)$ \\
\hline Share of German workers & -0.046 & $(0.118)$ \\
\hline Share of workers with 1 year tenure & 0.076 & $(0.041)$ \\
\hline Share of workers with 2 years tenure & $0.097 *$ & $(0.043)$ \\
\hline Share of workers with 3 years tenure & 0.017 & $(0.030)$ \\
\hline Share of workers with 4 years tenure & -0.001 & $(0.024)$ \\
\hline Share of workers with 5 years tenure & 0.001 & $(0.019)$ \\
\hline Share of workers with first job & 0.107 & $(0.075)$ \\
\hline Expected employment decrease & $0.194 * *$ & $(0.159)$ \\
\hline Good profit situation & -0.007 & $(0.005)$ \\
\hline Plant size $1-20$ & 0.021 & $(0.035)$ \\
\hline Plant size $21-200$ & 0.009 & $(0.015)$ \\
\hline Plant size 501-2000 & -0.026 & $(0.016)$ \\
\hline Plant size larger than 2000 & $-0.065 *$ & $(0.029)$ \\
\hline Medium-skilled * share medium-skilled & 0.059 & $(0.038)$ \\
\hline High-skilled $*$ share high-skilled & -0.000 & $(0.043)$ \\
\hline Female $*$ share females & $0.033 *$ & $(0.017)$ \\
\hline German * share Germans & $-0.131 * *$ & $(0.045)$ \\
\hline Tenure 3 years $*$ share tenure 3 years & -0.023 & $(0.036)$ \\
\hline Tenure 4 years $*$ share tenure 4 years & -0.000 & $(0.038)$ \\
\hline Tenure 5 years $*$ share tenure 5 years & 0.044 & $(0.039)$ \\
\hline Wage residual * share nominal wage reduction & -0.088 & $(0.090)$ \\
\hline Medium-skilled * share real wage reduction & $-0.047 *$ & $(0.024)$ \\
\hline High-skilled $*$ share wage reduction & $-0.278 * *$ & $(0.036)$ \\
\hline Female $*$ share wage reduction & $-0.052 * *$ & $(0.020)$ \\
\hline German * share wage reduction & 0.012 & $(0.021)$ \\
\hline Tenure 3 years $*$ share real wage reduction & $0.092 * *$ & $(0.020)$ \\
\hline Tenure 4 years $*$ share real wage reduction & $0.207 * *$ & $(0.023)$ \\
\hline Tenure 5 years $*$ share real wage reduction & $0.223 * *$ & $(0.023)$ \\
\hline Number of observations: 108,003 & \multicolumn{2}{|c|}{$\mathrm{R}^{2}$ (overall): 0.119} \\
\hline
\end{tabular}




\section{Table A4: Individual probability of job end}

\begin{tabular}{|c|c|c|}
\hline Regressand: dummy for job end & Plan & FE \\
\hline Regressors: & Coef. & $\mathrm{SE}$ \\
\hline Wage residual in previous year & $-0.109 * *$ & $(0.008)$ \\
\hline Medium-skilled (occupational degree) & $-0.031 * *$ & $(0.004)$ \\
\hline High-skilled (academic degree) & $-0.025 * *$ & $(0.005)$ \\
\hline Female & $0.030 * *$ & $(0.003)$ \\
\hline German & $-0.027 * *$ & $(0.004)$ \\
\hline Tenure 3 years & $-0.027 * *$ & $(0.004)$ \\
\hline Tenure 4 years & $-0.051 * *$ & $(0.004)$ \\
\hline Tenure 5 years & $-0.052 * *$ & $(0.004)$ \\
\hline Share of workers with job end & $0.882 * *$ & $(0.010)$ \\
\hline Relative employment change & -0.001 & $(0.005)$ \\
\hline Share of medium-skilled workers & -0.000 & $(0.044)$ \\
\hline Share of high-skilled workers & 0.034 & $(0.098)$ \\
\hline Share of female workers & -0.072 & $(0.076)$ \\
\hline Share of German workers & 0.132 & $(0.087)$ \\
\hline Share of workers with 1 year tenure & $-0.091 * *$ & $(0.033)$ \\
\hline Share of workers with 2 years tenure & $-0.142 * *$ & $(0.032)$ \\
\hline Share of workers with 3 years tenure & $0.060 *$ & $(0.030)$ \\
\hline Share of workers with 4 years tenure & 0.024 & $(0.024)$ \\
\hline Share of workers with 5 years tenure & 0.014 & (0.019) \\
\hline Share of workers with first job & $0.470 * *$ & $(0.068)$ \\
\hline Expected employment decrease & $-0.274 * *$ & $(0.084)$ \\
\hline Good profit situation & $-0.011 *$ & $(0.005)$ \\
\hline Plant size $1-20$ & 0.015 & $(0.029)$ \\
\hline Plant size 21-200 & -0.019 & $(0.012)$ \\
\hline Plant size 501-2000 & -0.004 & $(0.014)$ \\
\hline Plant size larger than 2000 & -0.026 & $(0.026)$ \\
\hline Tenure 3 years $*$ share tenure 3 years & $-0.082 *$ & $(0.032)$ \\
\hline Tenure 4 years $*$ share tenure 4 years & -0.028 & $(0.028)$ \\
\hline Tenure 5 years $*$ share tenure 5 years & 0.017 & $(0.029)$ \\
\hline Medium-skilled * share medium-skilled & -0.000 & $(0.020)$ \\
\hline High-skilled * share high-skilled & 0.057 & $(0.029)$ \\
\hline Female $*$ share females & 0.003 & $(0.014)$ \\
\hline German * share Germans & -0.070 & $(0.042)$ \\
\hline Wage residual * share job end & $0.135 * *$ & $(0.012)$ \\
\hline Tenure 3 years $*$ share job end & $0.066 * *$ & $(0.008)$ \\
\hline Tenure 4 years $*$ share job end & $0.091 * *$ & $(0.007)$ \\
\hline Tenure 5 years * share job end & $0.099 * *$ & $(0.007)$ \\
\hline Medium-skilled * share job end & $0.013 *$ & $(0.006)$ \\
\hline High-skilled $*$ share job end & $-0.021 *$ & $(0.008)$ \\
\hline Female $*$ share job end & $-0.045 * *$ & $(0.004)$ \\
\hline German * share job end & $0.030 * *$ & $(0.006)$ \\
\hline Number of observations: 108,003 & \multicolumn{2}{|c|}{$\mathrm{R}^{2}$ (overall): 0.589} \\
\hline
\end{tabular}

Notes: The data set used is the LIAB cross-sectional model, waves 2000-2006. Only workers in their first job and with at most 5 years tenure are included. $* * / *$ denotes statistical significance at the $1 / 5$ per cent level, where robust standard errors are clustered at the plant level. Reference group: low-skilled worker with 2 years of tenure working for a plant with 201-500 employees with neither a works council nor a collective agreement; further regressors included are 16 sector and 6 year dummies and a constant. In all interaction terms, the shares of workers with certain characteristics and of workers hit by a real wage reduction are centred around their sample means. 